\title{
Seed Morphology of Some Species of Indigofera (Fabaceae) from Saudi Arabia (Identification of Species and Systematic Significance)
}

\author{
F. A. Al-Ghamdi \\ Biology Department, Faculty of Science, KAU, Jeddah, KSA. \\ Email: ahmosman2000@yahoo.com \\ Received May $19^{\text {th }}, 2011$; revised June $13^{\text {th }}, 2011$; accepted July $28^{\text {th }}, 2011$.
}

\begin{abstract}
Seeds of 18 species of Indigofera L. were examined with the scanning electron microscope and the light microscope. Macro- and micromorphological characters, including seed shape, colour, size, surface, epidermal cell shape, anticlinal boundaries, outer periclinal cell wall and relief of outer cell walls, are presented. Two types of basic anticlinal cell wall boundaries and two types of relief outer cell walls are recognized and two different shapes of the outer periclinal cell wall are described. A key for the identification of the investigated taxa based on seed characters is provided.
\end{abstract}

Keywords: Seeds, Morphology, Indigofera, Fabaceae, Saudi Arabia

\section{Introduction}

Indigofera L. is a large pantropical genus in Fabaceae, belongs to the tribe Galegeae with c. 720 - 730 species [1]. The majority of taxa occur in Africa (c. 520) with other centres of diversity in Arabia to South East Asia, Mexico to subtropical North and South America, Australia and Madagascar. About 280 speci es of Indigofera occur in the flora of Southern Africa region [2,3].

In Saudi Arabia Indigofera is represented by about 20 species and five varieties [4,5].

Reference [14] discussed features of the Indigofera fruit relevant to the Australian taxa. Reference [6] were the first to recognize that all species have a persistent fruit-base that remains with the calyx and staminal tube after the valves of the open pod have fallen. Reference [1] considered this is a synapomorphy for the tribe. Reference [7] found that all endemic species of Indigofera in Australia have endocarp tannins present except in I. baileyi and I. mackinlayi.

Reference [8] mentioned that the Scanning electron microscopy provides great tool to achieve more accurate seed identification, which could be used as a routine technique in the study of the Spermoderm Morphology $[9,10]$.

Reference [11] established nine categories in his investigation of 340 species of Paplionoideae. Also, Reference [12] found three categories of Lersten's estab- lishments. Belonging to the seeds testa patterns, Reference [11] illustrated a simple reticulate in $T$. candida.

The aim of the present study is to investigate macroand micro-morphological characters of genus Indigofera seeds in Saudi Arabia, using Stereo- and Scanning Electron microscopy, which expected to be reliable for distinguishing the studied taxa. The work is mainly concentrated on collection of field work as well as herbarium collections from King Abdulaziz University KUH, KSU and RIY.

\section{Material and Methods}

The fresh plant samples were collected from the sites which were reported by $[4,5,13,14]$, with field survey of the species throughout Saudi Arabia regions. The plant specimens nomenclatured according to [4,5,15]. Mature seeds were collected from dehiscent legumes, then cleaned with alcohol and kept for drying. The macro-morphological characters of the studied seeds were carried out using of Stereo-microscopy (Stemi2000-C) and the measurements, shapes, colour, and the position of hilum were recorded. On the other hand, the mature seeds of the investigated taxa were chosen for SEM study, where seeds were mounted on stubs using double face carbon tape, and coated with gold/palladium at $1.2 \mathrm{kv}$ for 15 minutes under high vacuum in an ion sputter coating unit. The examined samples were detected and photographed using Scanning Electron Microscopy (Jeol JSM-20). The 
terminology used here follows authors such as [10] and [16].

\section{Results}

Fruit and Seed characters are very important to separate among species in the genus Indigofera.

\subsection{Fruits Colour}

The colour of fruits is very important to separate among the studied species. The colour varies from brown, light brown, deep brown, grayish, creamer, deep brown to creamer. It is deep brown in I. argentea and I. spicata, light brown in I. sessiliflora and I. spiniflora, grayish in $I$. Arabica and I. Linifolia, creamer in I. intricata, deep brown to creamer in I. oblongifolia and brown in the rest of the species. The fruit colour is used to distinguish between species of I. Arabica, I. Linifolia, I. intricata and I. oblongifolia from the other species (see Table 1).

Table 1. The macro-morphological characters of the studied Indigofera seeds.

\begin{tabular}{|c|c|c|c|c|c|c|c|c|c|c|c|}
\hline \multirow{3}{*}{ Таха } & \multicolumn{4}{|c|}{ Fruits } & \multicolumn{7}{|c|}{ Seeds } \\
\hline & \multirow{2}{*}{ colour } & \multirow{2}{*}{$\begin{array}{c}\text { constriction } \\
\text { level }\end{array}$} & \multirow{2}{*}{$\begin{array}{l}\text { len. } \\
\text { (cm) }\end{array}$} & \multirow{2}{*}{ shape } & \multirow{2}{*}{$\begin{array}{l}\text { number } \\
\text { (mean) }\end{array}$} & \multirow{2}{*}{ colour } & \multirow{2}{*}{$\begin{array}{l}\text { hilum } \\
\text { position }\end{array}$} & \multirow{2}{*}{$\begin{array}{l}\text { size } \\
(\mathrm{mm})\end{array}$} & \multirow{2}{*}{ shape - } & \multicolumn{2}{|c|}{ ornament. } \\
\hline & & & & & & & & & & pr. & colour \\
\hline 1. I. amorphoides & $\mathrm{Br}$. & - & 0.6 & St., Cy. & $1-2(-3)$ & $\mathrm{Br}$. & Subcentral & $0.21 \times 0.16$ & Irr. & - & - \\
\hline 2. I. arabica & Gr. & - & 1.3 & Fl., Fic. & 4 & $\mathrm{Br}$. & Central & $0.17 \times 0.14$ & Irr. & - & - \\
\hline 3. I. argentea & D. Br. & - & 1.5 & St., Cy. & 10 & D. Br. & Subcentral & $0.95 \times 0.12$ & Rect. & - & - \\
\hline 4. I. arrecta & $\mathrm{Br}$. & - & 3.2 & St., Cy. & $7-9$ & Black & Subcentral & $0.2 \times 0.15$ & Irr. & - & - \\
\hline 5. I. articulata & $\mathrm{Br}$. & De. & 1.1 & \pm De., Cy. & $3-(-4)$ & D. oily & Central & $0.22 \times 0.22$ & Cir. & - & - \\
\hline 7. I. colutea & $\mathrm{Br}$. & - & 1.5 & St., Cy. & 6 & Oily & Subcentral & $0.15 \times 0.1$ & Cir. & - & - \\
\hline 8. I. hochstetteri & $\mathrm{Br}$. & - & 1.7 & De., Fl. & 9 & $\mathrm{Br}$. & Subcentral & $0.18 \times 0.16$ & Cir. & + & $\mathrm{Br}$. \\
\hline 9. I. intricata & Cr. & - & 2.5 & St., Cy. & 15 & L. Br./Or. & Subcentral & $0.14 \times 0.13$ & Cir. & - & - \\
\hline 10. I. Linifolia & Gr. & - & 0.3 & Cir. & 1 & $\mathrm{Br}$. & Central & $0.08 \times 0.09$ & Cir. & + & $\mathrm{Br}$. \\
\hline 11. I. oblongifolia & D. Br. to Cr. & De. & 2.2 & \pm De., Cy. & 6 & $\mathrm{Br}$. & Subcentral & $0.14 \times 0.1$ & Irr. & - & - \\
\hline 12. I. sessiliflora & L. Br. & De. & 1.0 & St., Cy. & 7 & D. oily & Central & $0.11 \times 0.11$ & Cir. & + & Gr. - oily \\
\hline 14. I. spiniflora & L. Br. & De. & 3.5 & $\mathrm{Cu}$. & 9 & $\mathrm{Br}$. & Central & $0.25 \times 0.12$ & Irr. & + & Pu. to D. pu \\
\hline 15. I. spinosa & $\mathrm{Br}$. & - & 1.7 & St., Cy. & $6-7$ & Cr. & Subcentral & $0.15 \times 0.13$ & Rect. & + & Oily-D. Br. \\
\hline 16. I. tinctoria & $\mathrm{Br}$. & - & 2.5 & St., Cy. & $7-9$ & Oily/Gr. & Subcentral & $0.25 \times 0.16$ & Rect. & + & D. Br. \\
\hline 17. I. trita var. subulata & $\mathrm{Br}$. & - & $1.0-2.5$ & St., An. & $7-10$ & D. Br. & Subcentral & $0.17 \times 0.1$ & Irr. & - & - \\
\hline 18. I. volkensii & $\mathrm{Br}$. & V. Sh. & $1.5-2.0$ & St., Cy. & 6 & $\mathrm{Br}$. & Subcentral & $0.08 \times 0.1$ & Rect. & + & $\mathrm{Pu}-\mathrm{Bl}$. \\
\hline
\end{tabular}

Bl. = black; Br. = brown; Cir. = circular; Cr. = creamer; Cu. = curved; D. Br. = dark brown; De. = deep; Gr. = grayish; De., Cy. = deflexed, cylindrical; \pm De., Cy. = little deflexed, cylindrical; De., Fl. = deflexed, flat; Fl., Fic. = flat, fickle; Irr. = irregular; Len. = length; L. Br. = light brown; L. Br./Or. = light brown to orange; Ornament. = ornamentation; Pr. = present; Pu. = purple; Rect. = rectangular; Sh. = shallow; V. Sh. = very shallow; St., An. = straight, angular, St., Cy. = straight, cylindrical. 


\subsection{Fruits Constriction Level}

The level of fruits constriction also is important feature to distinguish between even and constricted fruits in studied species. The fruits have deep constrictions in $I$. articulate, I. oblongifolia, I. sessiliflora and I. spiniflora, with shallow constrictions in I. coerulea var. occidentalis and possess very shallow constrictions in I. volkensii. The fruits of the remained studied species are even. The Fruits constriction level is also useful to distinguish between species of I. articulate, I. oblongifolia, I. sessiliflora, I. spiniflora, I. coerulea var. occidentalis and I. volkensii. from the other investigated species (see Table 1).

\subsection{Fruits Length}

Length of fruits ranges from $0.6 \mathrm{~cm}-3.5 \mathrm{~cm}$ (see Table 2). The smallest fruits are those of $I$. species $(0.6 \mathrm{~cm})$ and the largest are those of $I$. spiniflora $(3.5 \mathrm{~cm})$. Fruits length of other taxa ranged between $(1.0 \mu \mathrm{m}-3.2 \mu \mathrm{m})$. Fruits length contributes to differentiate between the related species of $I$. amorphoides, I. spiniflora, I. arrecta $(3.2 \mathrm{~cm})$ from the other species (Table 1).

\subsection{Fruits Shape}

Fruits are more or less similar in shape being straight, cylindrical; deflexed, cylindrical; flat, fickle; deflexed, flat; circular; curved or straight, angular. They are more or little deflexed, cylindrical in I. articulate, I. coerulea var. occidentalis and I. oblongifolia, Flat, fickle in $I$. Arabica, Deflexed, flat in I. hochstetteri, circular in $I$. Linifolia, curved in I. spiniflora and finally straight, angular in I. trita var. subulata. The fruits shape also contributes to differentiate I. articulate, I. coerulea var. occidentalis, I. oblongifolia, I. Arabica, I. hochstetteri, I. Linifolia, I. spiniflora and I. trita var. subulata. species from the other investigated taxa which are characterized by straight, cylindrical fruits (Table 1).

\subsection{Seeds Number (Mean)}

Number of seeds varies greatly among the examined taxa, the high number of seeds is 15 seeds in I. intricata and the low number is 1 - 2 in I. Linifolia and I. amorphoides, while the number of seeds in the rest of the studied species are ranged from 3 - 10 seeds. The seed number was found useful to separate species of I. intricata, I. Linifolia and I. amorphoides from the other species (see Table 1).

\subsection{Seeds Colour}

The colour of seeds is of high diagnostic and systematic interest among taxa. The colour varies from brown, dark oily, dark brown, oily, black, light oily, light brown/orange and creamer to oily/grayish. The seeds colour is brown in I. amorphoides, I. Arabica, I. hochstetteri, I. Linifolia, I. oblongifolia, I. spiniflora and I. volkensii, dark oily in I. articulata, I. sessiliflora and I. spicata, dark brown in I. argentea and I. trita var. subulata, oily in I. colutea, with black colour in I. arrecta, light oily colour in I. coerulea var. occidentalis, light brown/orange in I. intricate, creamer in I. spinosa and finally oily/grayish in I. tinctoria. The Seeds colour is also used to distinguish between species of I. arrecta, I. coerulea var. occidentalis, I. intricate, I. spinosa and I. tinctoria from the other investigated taxa where there are more than one species for every colour (Figures 1-18 and Table 1).

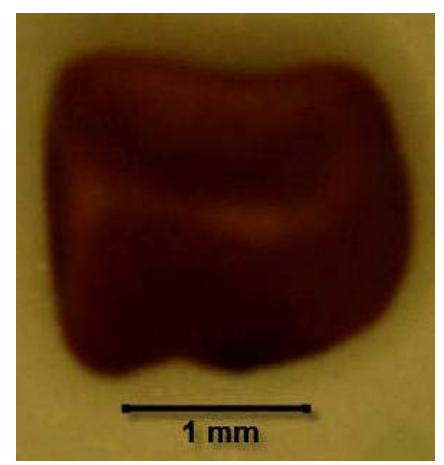

(a)

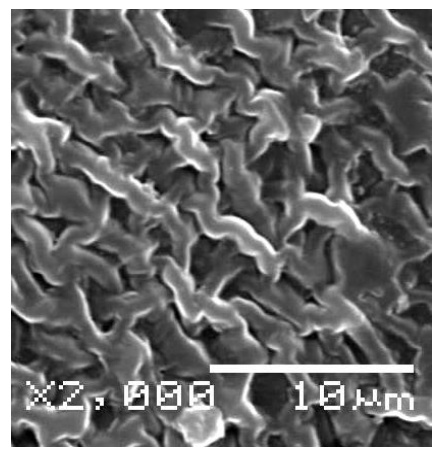

(b)

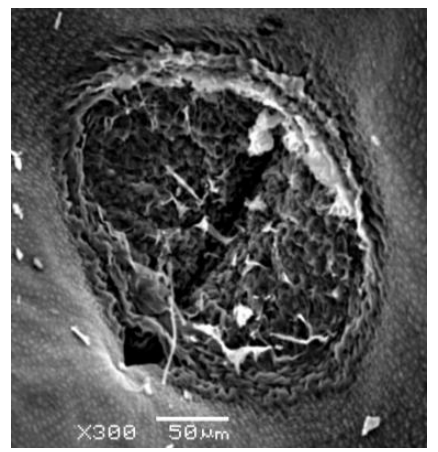

(c)

Figure 1. I. amorphoides: (a) entire seed; (b) enlargement of seed coat; (c) Hilum shape. 


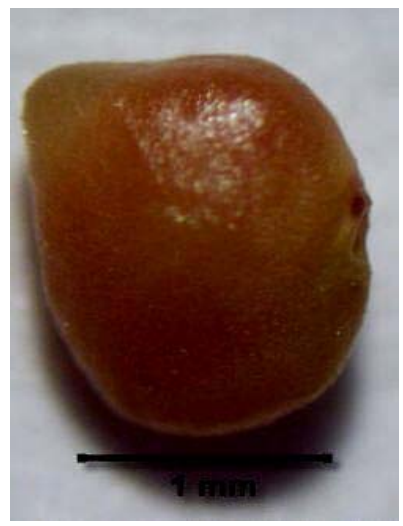

(a)

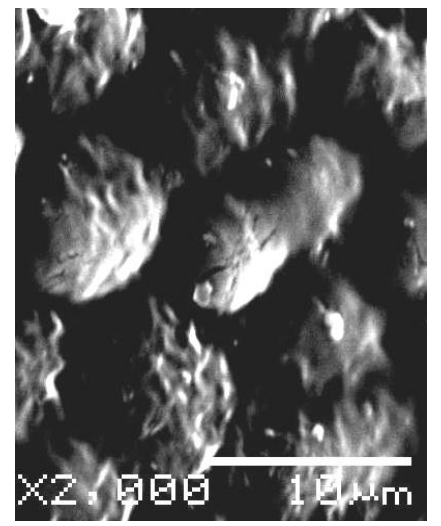

(b)

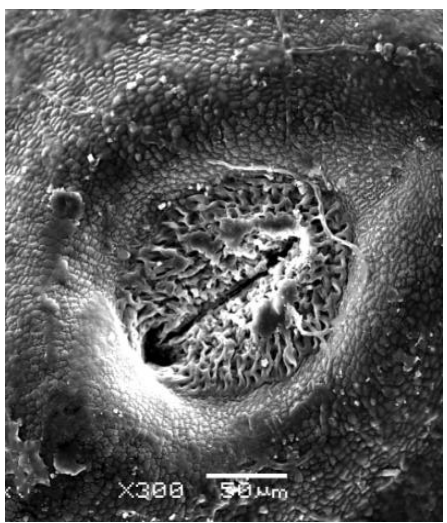

(c)

Figure 2. I. arabica: (a) entire seed; (b) enlargement of seed coat; (c) Hilum shape.

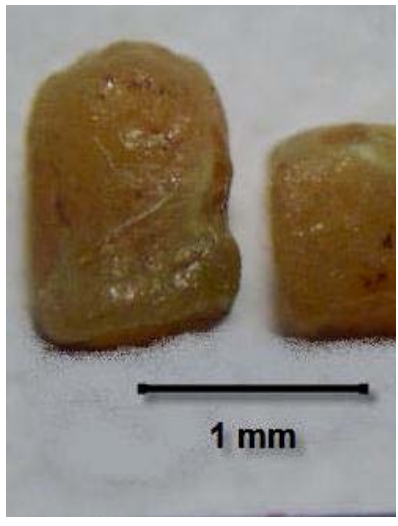

(a)

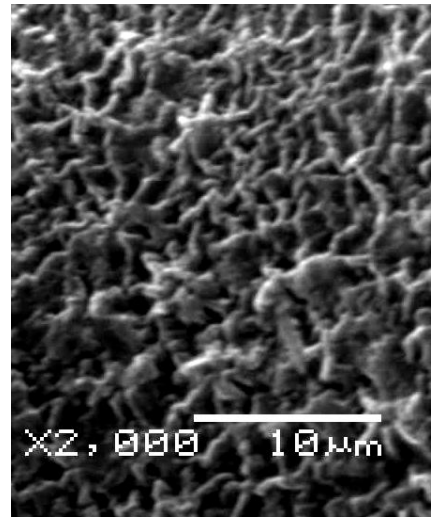

(b)

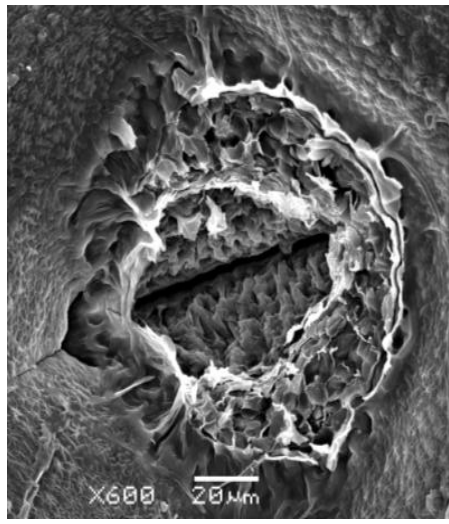

(c)

Figure 3. I. argentea: (a) entire seed; (b) enlargement of seed coat; (c) Hilum shape.

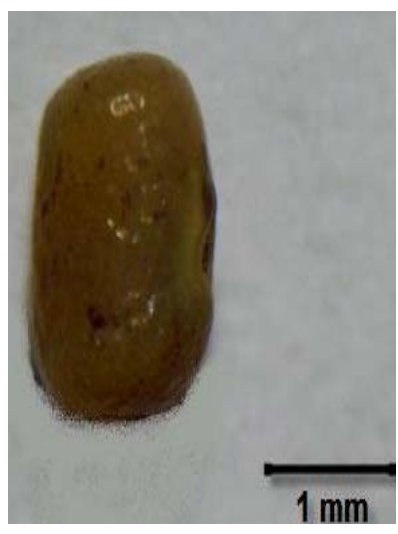

(a)

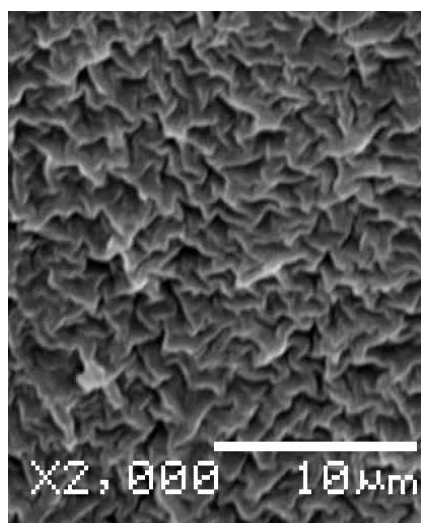

(b)

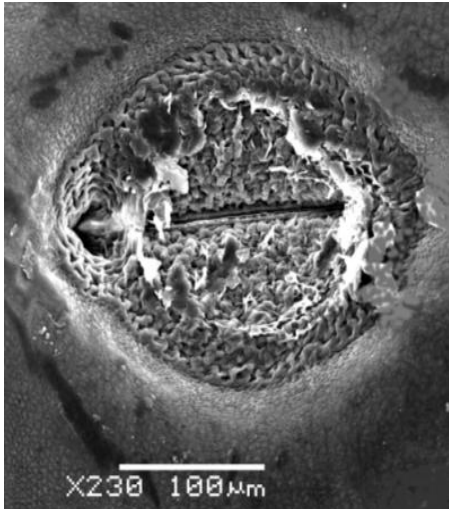

(c)

Figure 4. I. arrecta: (a) entire seed; (b) enlargement of seed coat; (c) Hilum shape.

\subsection{Hilum Position}

There are two forms to hilum position, it is may be subcentral or central. Hilum is central in I. Arabica, I. articulate, I. Linifolia, I. sessiliflora, I. spicata and I. spiniflora and subcentral in the remained species. Position of the hilum was useful to distinguish between two groups in the studied taxa, group with subcentral hilum and another one with central hilum (Figures 1-18 and Table 1). 


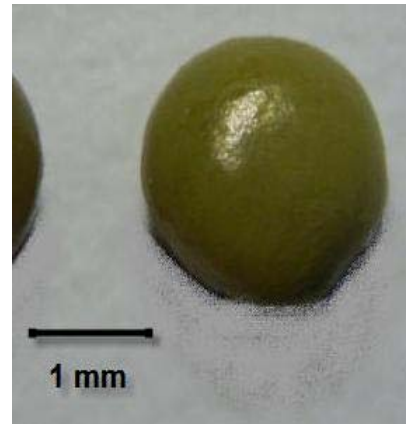

(a)

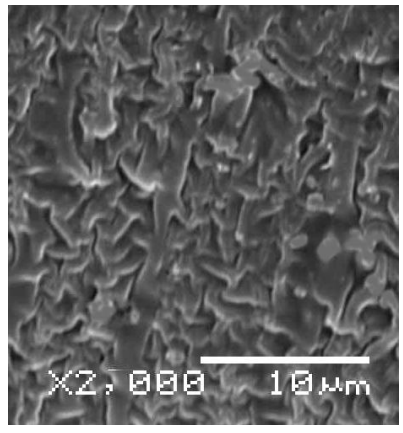

(b)

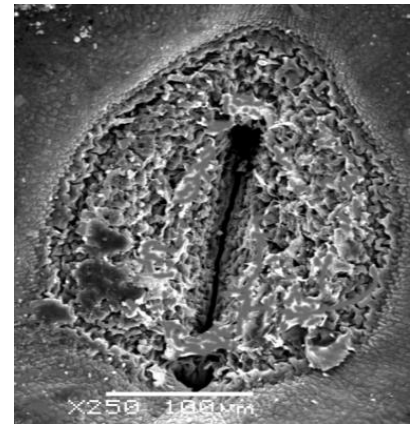

(c)

Figure 5. I. articulata: (a) entire seed; (b) enlargement of seed coat; (c) Hilum shape.

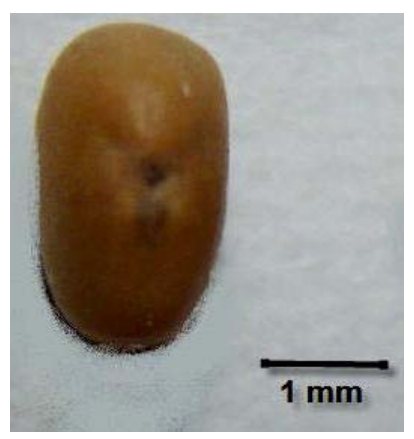

(a)

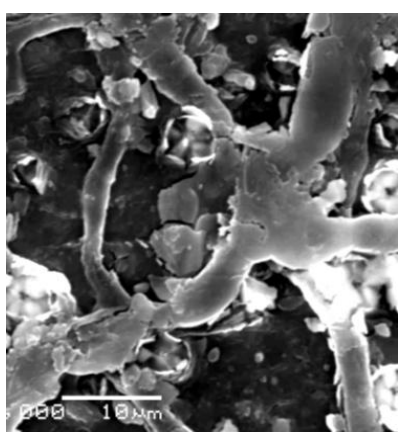

(b)

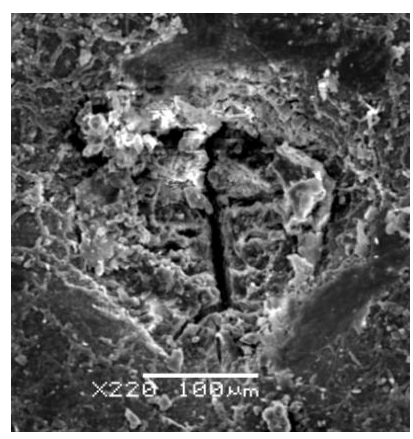

(c)

Figure 6. I. coerulea var. occidentalis: (a) entire seed; (b) enlargement of seed coat; (c) Hilum shape.

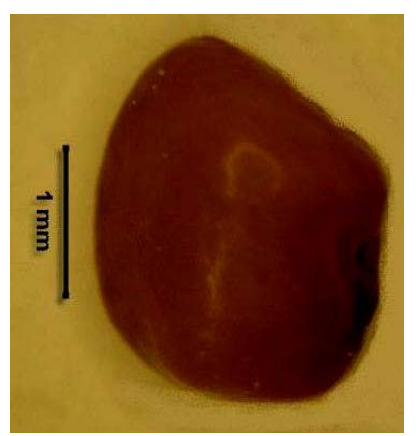

(a)

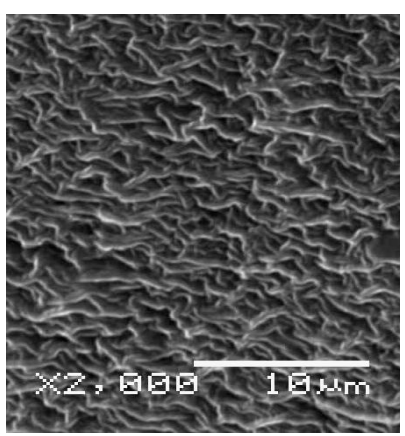

(b)

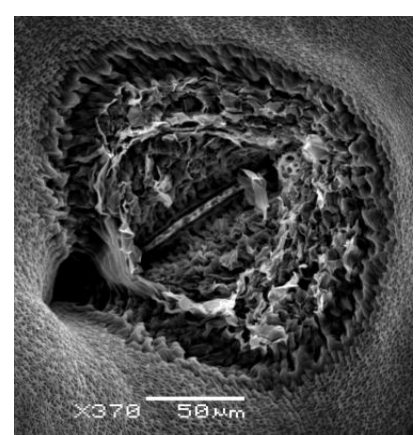

(c)

Figure 7. I. colutea: (a) entire seed; (b) enlargement of seed coat; (c) Hilum shape.

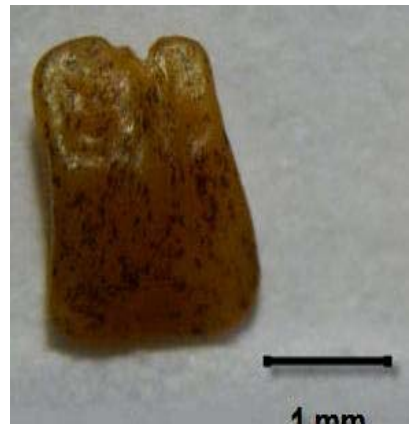

(a)

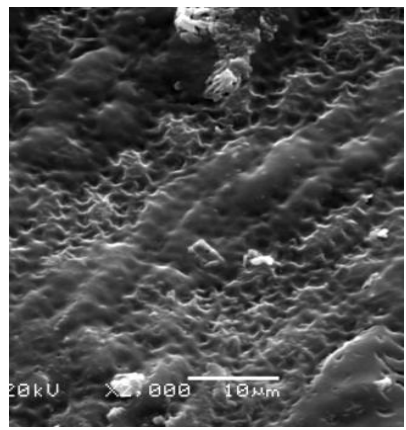

(b)

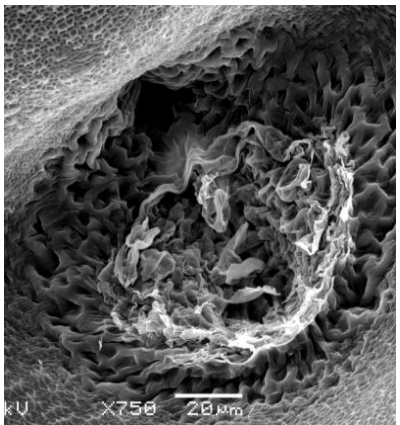

(c)

Figure 8. I. hochstetteri: (a) entire seed; (b) enlargement of seed coat; (c) Hilum shape. 


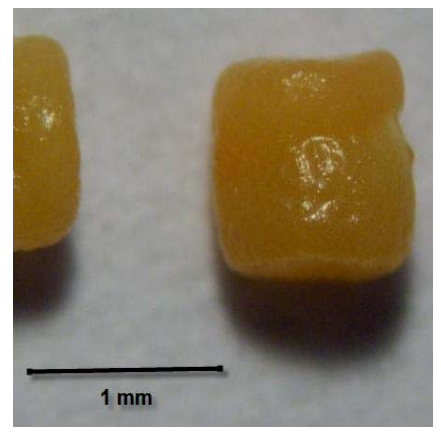

(a)

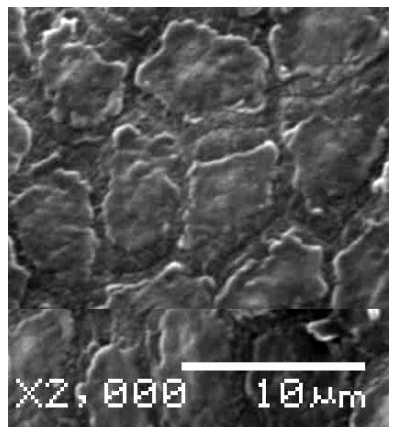

(b)

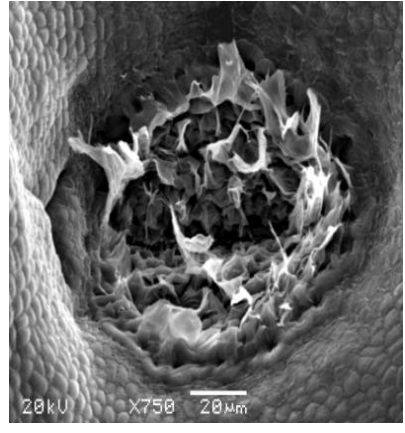

(c)

Figure 9. I. intricate: (a) entire seed; (b) enlargement of seed coat; (c) Hilum shape.

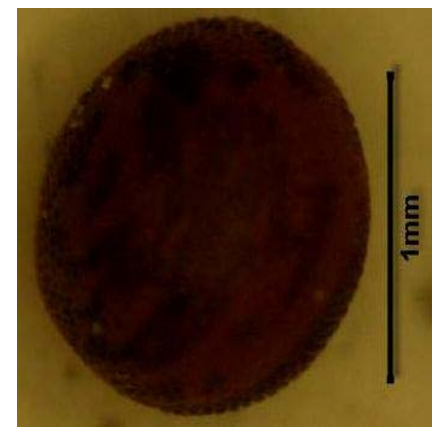

(a)

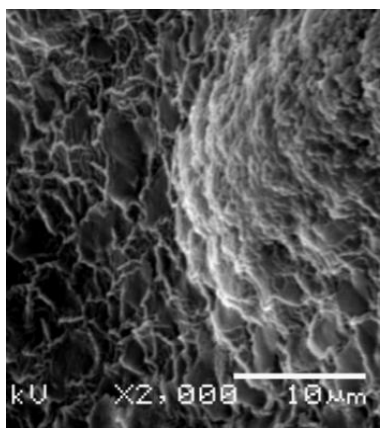

(b)

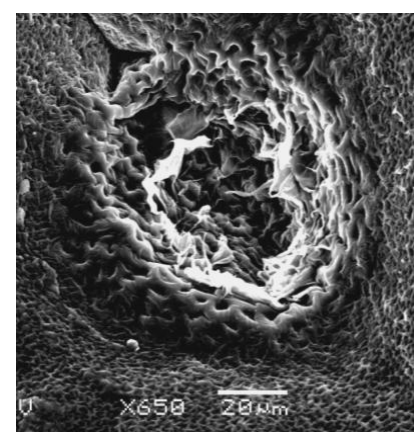

(c)

Figure 10. I. linifolia: (a) entire seed; (b) enlargement of seed coat; (c) Hilum shape.

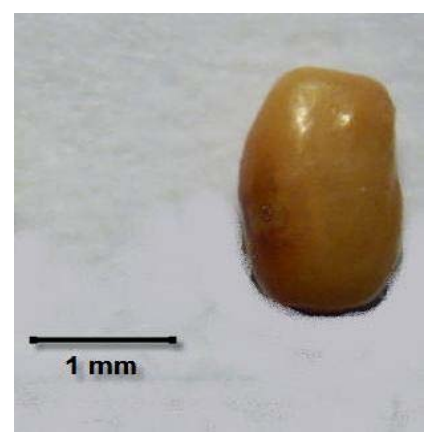

(a)

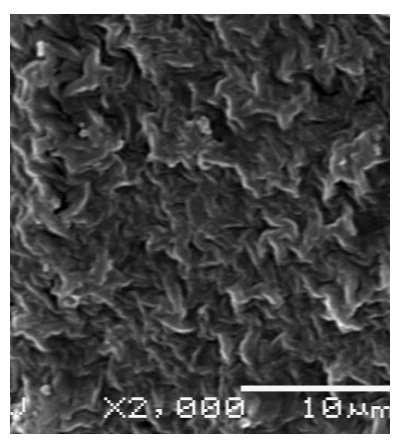

(b)

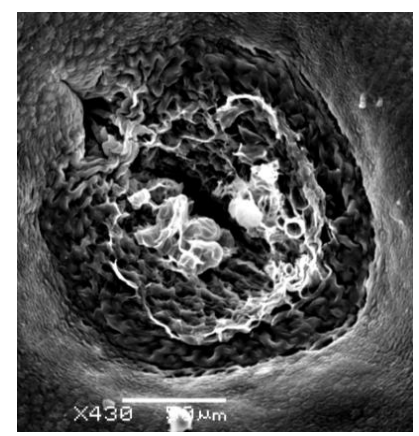

(c)

Figure 11. I. oblongifolia: (a) entire seed; (b) enlargement of seed coat; (c) Hilum shape.

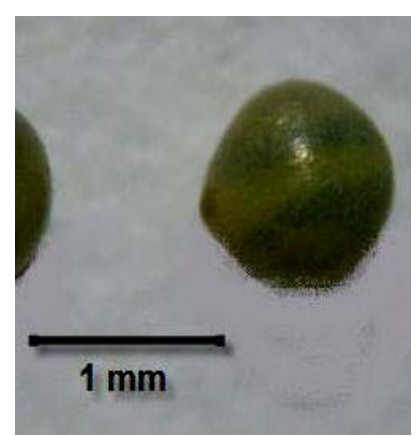

(a)

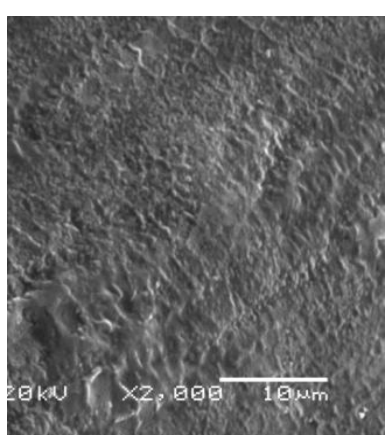

(b)

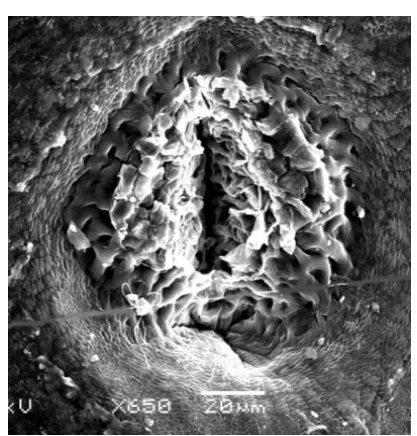

(c)

Figure 12. I. sessiliflora: (a) entire seed; (b) enlargement of seed coat; (c) Hilum shape. 


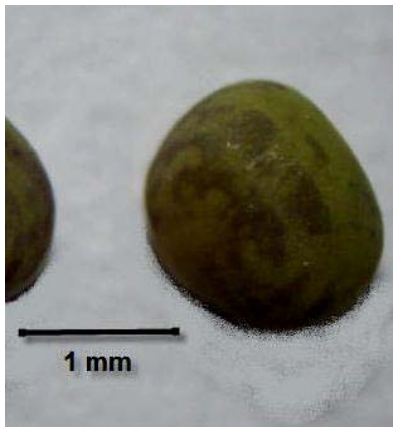

(a)

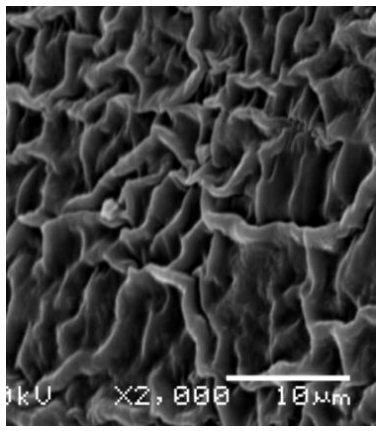

(b)

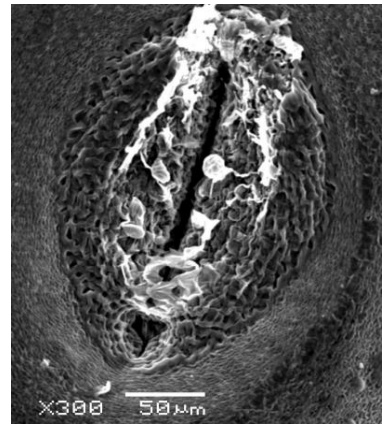

(c)

Figure 13. I. spicata: (a) entire seed; (b) enlargement of seed coat; (c) Hilum shape.

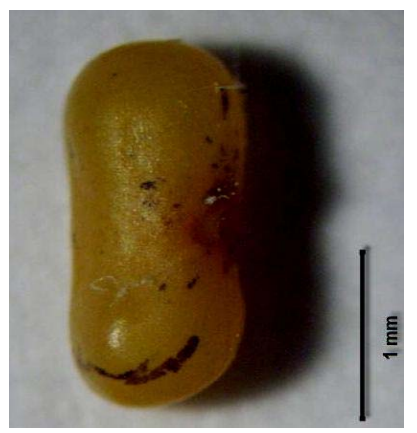

(a)

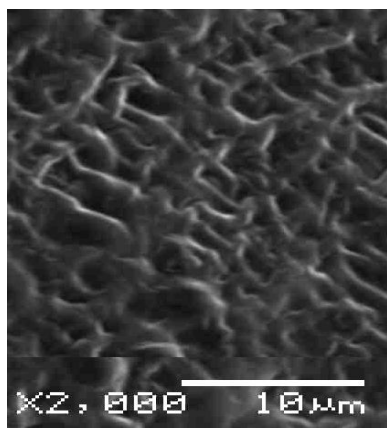

(b)

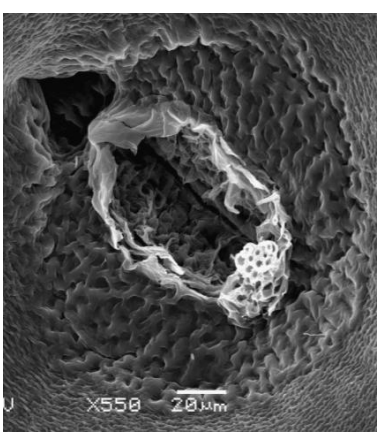

(c)

Figure 14. I. spicata: (a) entire seed; (b) enlargement of seed coat; (c) Hilum shape.

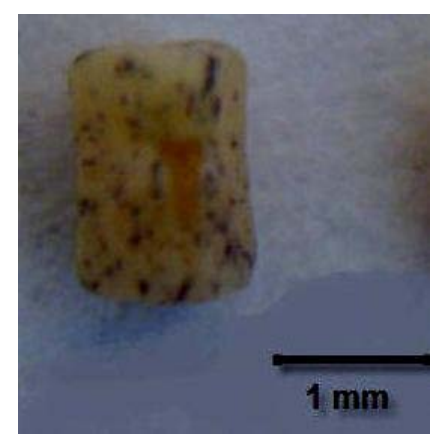

(a)

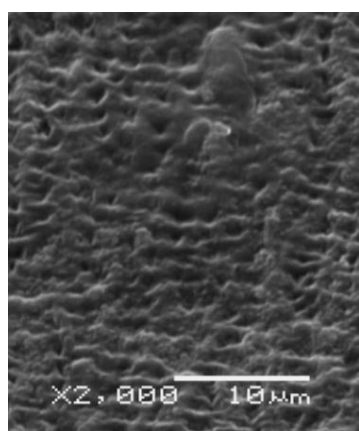

(b)

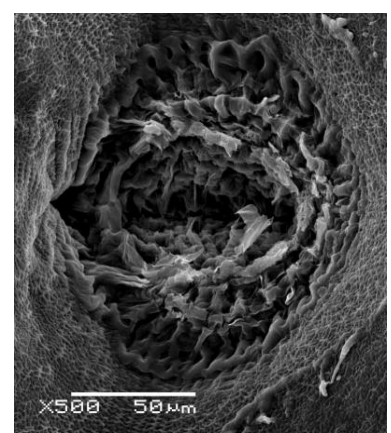

(c)

Figure 15. I. spinosa: (a) entire seed; (b) enlargement of seed coat; (c) Hilum shape.

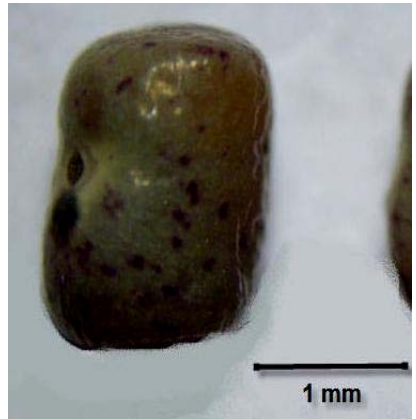

(a)

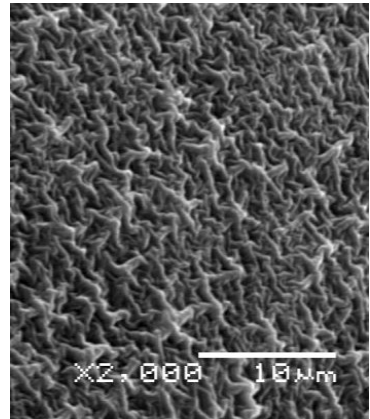

(b)

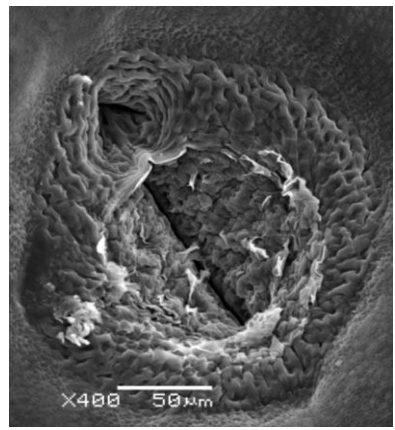

(c)

Figure 16. I. tinctoria: (a) entire seed; (b) enlargement of seed coat; (c) Hilum shape. 


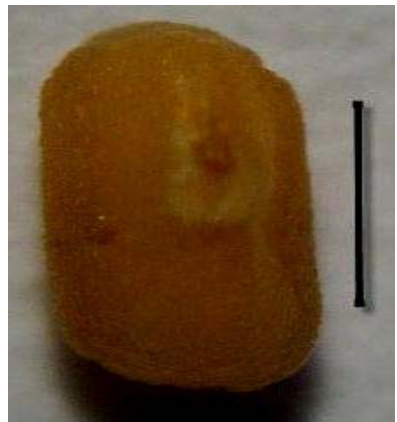

(a)

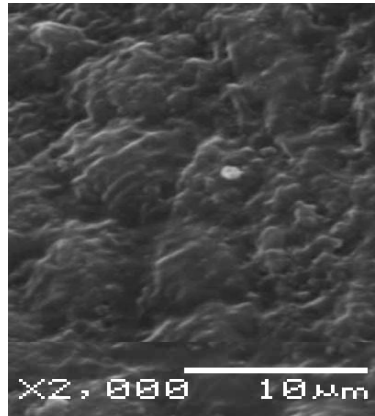

(b)

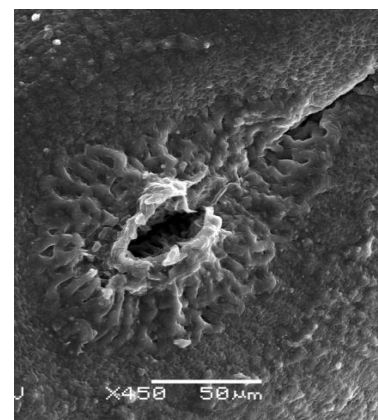

(c)

Figure 17. I. trita var. subulata: (a) entire seed; (b) enlargement of seed coat; (c) Hilum shape.

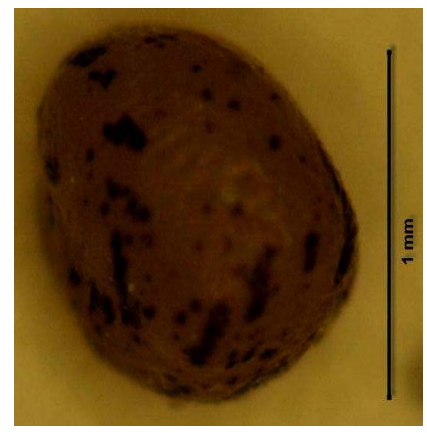

(a)

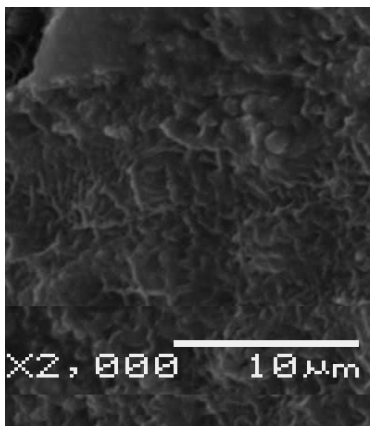

(b)

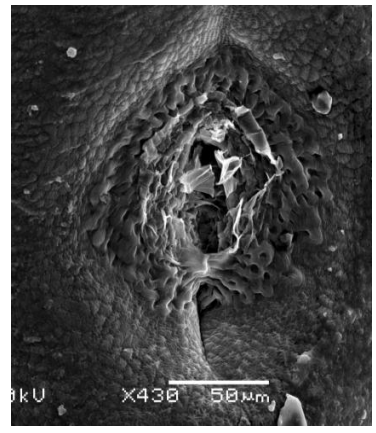

(c)

Figure 18. I. volkensii: (a) entire seed; (b) enlargement of seed coat; (c) Hilum shape.

Table 2. SEM observations on seeds surface character of 18 species of Indigofera (Leguminosae).

\begin{tabular}{|c|c|c|c|c|c|c|c|c|c|c|}
\hline \multirow{4}{*}{ Taxa } & \multicolumn{10}{|c|}{ Seeds surface character texture } \\
\hline & \multicolumn{2}{|c|}{ ridged } & \multicolumn{6}{|c|}{ reticulate } & \multirow{3}{*}{ scaled } & \multirow{3}{*}{ rough } \\
\hline & \multirow{2}{*}{ wrinkly } & \multirow{2}{*}{ groovy } & \multicolumn{2}{|c|}{ simple } & \multicolumn{3}{|c|}{ compound (bireticulate) } & \multirow[t]{2}{*}{ opened } & & \\
\hline & & & irregular & regular & I & II & III & & & \\
\hline 1. I. amorphoides & - & - & - & - & - & + & - & - & - & - \\
\hline 2. I. arabica & + & - & - & - & - & - & - & - & - & - \\
\hline 3. I. argentea & - & - & - & - & + & - & - & - & - & - \\
\hline 4. I. arrecta & - & - & + & - & - & - & - & - & - & - \\
\hline 5. I. articulata & - & - & + & - & - & - & - & - & - & - \\
\hline 6. I. coerulea var. occidentalis & - & - & + & - & - & - & - & - & - & - \\
\hline 7. I. colutea & - & - & - & - & - & + & - & - & - & - \\
\hline 8. I. hochstetteri & - & - & - & - & - & - & - & - & - & + \\
\hline 9. I. intricata & - & - & - & - & - & - & - & - & + & - \\
\hline 10. I. linifolia & - & + & - & - & - & - & - & - & - & - \\
\hline 11. I. oblongifolia & - & - & - & - & - & + & - & - & - & - \\
\hline 12. I. sessiliflora & - & - & - & - & - & - & - & + & - & - \\
\hline 13. I. spicata & - & - & - & - & + & - & - & - & - & - \\
\hline 14. I. spiniflora & - & - & - & - & - & + & - & - & - & - \\
\hline 15. I. spinosa & - & - & - & + & - & - & - & - & - & - \\
\hline 16. I. tinctoria & - & - & - & - & - & - & + & - & - & - \\
\hline 17. I. trita var. subulata & + & - & - & - & - & - & - & - & - & - \\
\hline 18. I. volkensii & $+*$ & - & - & - & - & - & - & - & - & - \\
\hline
\end{tabular}

Por.-Sret. = porate to simplereticulate; $+=$ the feature present; $-=$ the feature absent; $+*=$ wrinkly ridged to bireticulate; $\mathrm{I}=$ the outer reticulum is thin and inner one is thick; II = the outer reticulum is thick and the inner one is thin; III = the outer and the inner reticulum are the similar. 


\subsection{Seed Size}

Seed dimensions vary greatly among the examined taxa, the largest seeds in $I$. argentea have a diameter of $0.95 \times$ $0.12 \mathrm{~mm}$, and the smallest seeds measure $0.08 \times 0.09-$ $0.1 \mathrm{~mm}$ in I. Linifolia and I. volkensii, while the rest of the studied species have seeds their dimensions from $0.11 \times 0.11-0.25 \times 0.18 \mathrm{~mm}$. The seed size was found useful to separate species of I. argentea, I. Linifolia and $I$. volkensii from the other species (see Table 1).

\subsection{Seeds Shape}

The shape of seeds is showed a large variation among the investigated taxa. Most of seeds have circular shape and others are irregular or rectangular in shape (Table 2). Seeds are rectangular in I. argentea, I. coerulea var. occidentalis, I. spinosa, I. tinctoria and I. volkensii; irregular in I. amorphoides, I. Arabica, I. arrecta, I. oblongifolia, I. spiniflora and I. trita var. subulata and circular in the rest of the studied taxa (Figures 1-18). The shape of seeds was found useful to distinguish between three groups in the studied Indigofera species (Figures 1-18 and Table 1).

\subsection{Seeds Ornamentation}

Seeds ornamentation is a significant character to separate among studied, ornamented species of Indigofera. The ornamentation of seeds present in some species like $I$. hochstetteri, I. Linifolia, I. sessiliflora, I. spicata, I. spiniflora, I. spinosa, I. tinctoria, I. volkensii and absent in the others. Also ornamentation colour was found useful to distinguish among the ornamented seeds. The colour varies from brown in I. hochstetteri and I. Linifolia, dark brown in $I$. spicata and I. tinctoria, green to oily in $I$. sessiliflora, purple to dark purple in I. spiniflora, oily to dark brown in I. spinosa and finally purple to black in $I$. volkensii. The ornamentation of seeds was found useful to separate between two groups of seeds, ornamented and not ornamented seeds. Also with ornamentation colour we can distinguish among I. sessiliflora, I. spiniflora, I. spinosa and $I$. volkensii from the others ornamented species (Figures 1-18 and Table 1).

\subsection{Character of Seeds Surface Texture}

The character of Seeds surface texture can be of considerable diagnostic and systematic value. The texture of seeds surface varies from reticulate, ridged, scaled to rough (Table 2). There are three forms of reticulation, it may be opened, simple or compound (bireticulate). Opened reticulate surface present in I. sessiliflora, simple reticulate seeds surface texture may be regular or irregular, simple regular reticulate surface exists in I. spinosa, but simple irregular reticulate surface appeared in I. arrecta, I. articulate and $I$. coerulea var. occidentalis. Compound or bireticulate surface also has three forms, it may be thin in the outer reticulum and thick in the inner one, thick in the outer reticulum and thin in the inner layer or the outer and the inner reticulum have the same thickness, the first form present in I. argentea and I. spicata, the second form present in I. amorphoides, I. colutea, I. oblongifolia and I. spiniflora and the third form are showed only in I. tinctoria. The ridged seeds surface texture also are appeared in two froms, it may be wrinkly ridged in I. Arabica and I. trita var. subulata, wrinkly ridged to bireticulate in $I$. volkensii, or groovy ridged only in I. linifolia. Scaled surface also are existed only in I. intricata and rough surface is appeared only in $I$. hochstetteri. It is cleared that, the texture of the seeds surface is essential and of great importance property to distinguish among the investigated taxa, it is used to distinguish clearly among species of $I$. spinosa, I. sessiliflora, I. linifolia, I. intricate, I. tinctoria and I. hochstetteri.

\subsection{The Shape of Hilum}

The shape of hilum among the investigated taxa showed a large variation. Shape of hilum varies from ovate, elliptic or circular in shape (Table 3). Hilum is wide ovate in I. amorphoides, I. hochstetteri, I. linifolia, I. oblongifolia, I. sessiliflora, I. spiniflora and I. spinosa, ovate in I. coerulea var. occidentalis and I. trita var. subulata, only elliptic in I. arabica, I. articulate and I. volkensii, wide elliptic in I. argentea, I. arrecta, I. intricata, I. spicata and $I$. tinctoria, finally hilum has circular shape only in $I$. colutea.

\section{Discussion}

From the above it can be seen that a clear cut distinction can be made among taxa based on the main external seed morphology. The variations observed in the seed coat patterns at high magnification were generally speciesspecific. Seeds texture characters applied to the species of Indigofera L. in Egypt proved to be useful in the distinction between four types of which two types represented by only one species, for example, the scaled texture type was discerned in only in I. intricata, rough texture type was observed also only in I. hochstetteri. Moreover, in I. arabica, I. linifolia, I. trita var. subulata and $I$. volkensii species two forms of the ridged texture type was observed, the first wrinkly ridged texture form was showed in I. arabica, I. trita var. subulata and I. volkensii and the second groovy ridged form are distinguished only in I. linifolia. The latest fourth texture type 
Table 3. Tubular summary showing the shape of hilum in investigated species of Indigofera.

\begin{tabular}{|c|c|c|c|c|c|}
\hline Taxa & wide ovate & ovate & elliptic & wide elliptic & circular \\
\hline 1. I. amorphoides & + & - & - & - & - \\
\hline 2. I. arabica & - & - & + & - & - \\
\hline 3. I. argentea & - & - & - & + & - \\
\hline 4. I. arrecta & - & - & - & + & - \\
\hline 5. I. articulata & - & - & + & - & - \\
\hline 6. I. coerulea var. occidentalis & - & + & - & - & - \\
\hline 7. I. colutea & - & - & - & - & + \\
\hline 8. I. hochstetteri & + & - & - & - & - \\
\hline 9. I. intricata & - & - & - & + & - \\
\hline 10. I. linifolia & + & - & - & - & - \\
\hline 11. I. oblongifolia & + & - & - & - & - \\
\hline 12. I. sessiliflora & + & - & - & - & - \\
\hline 13. I. spicata & - & - & - & + & - \\
\hline 14. I. spiniflora & + & - & - & - & - \\
\hline 15. I. spinosa & + & - & - & - & - \\
\hline 16. I. tinctoria & - & - & - & + & - \\
\hline 17. I. trita var. subulata & - & + & - & - & - \\
\hline 18. I. volkensii & - & - & + & - & - \\
\hline
\end{tabular}

$+=$ the feature present; $-=$ the feature absent.

is the reticulate type, it was observed in three forms, the first form is the opened reticulate texture was discovered only in I. sessiliflora, the second one was the simple reticulate texture, it may be with irregular reticulation as shown in I. arrecta, I. articulata and I. coerulea var. occidentalis or has regular reticulation as observed only in $I$. spinosa and the third form was the compound (bireticulate) reticulate texture, there are three probabilities for the outer and the inner layers of the reticulum, in the first probability the outer reticulum is thick and the inner one is thin and this was showed in both I. argentea and I. spicata, and in the second probability the outer reticulum is thick and the inner one is thin and was observed in $I$. amorphoides, I. colutea, I. oblongifolia and I. spiniflora, but in the third one the outer and the inner reticulum have the same thickness, this was showed only in I. tinctoria.

Fruit and Seed morphological characters were helpful in distinguishing various species (Table 2). The smallest seed is those of $I$. Linifolia $(0.08 \times 0.09 \mathrm{~mm})$ and the largest are those of $I$. argentea $(0.95 \times 0.12 \mathrm{~mm})$. Seeds size of other taxa ranged between $(0.08 \times 0.1-0.25 \times$ $0.18 \mathrm{~mm}$ ). Seeds are more or less similar in shape being straight, cylindrical; flat, fickle; deflexed, cylindrical; deflexed, flat; circular; straight, angular to curved.

Hilum shape contributes to differentiate among the related species of Indigofera L.; I. amorphoides, I. hoch- stetteri, I. linifolia, I. oblongifolia, I. sessiliflora, I. spiniflora, I. spinosa, I. coerulea var. occidentalis and I. trita var. subulata are characterized by ovate to wide ovate hilum, while I. arabica, I. articulata, I. volkensii, I. argentea, I. arrecta, I. intricata, I. spicata and I. tinctoria exhibit elliptic to wide elliptic hilum and only I. colutea that has circular hilum.

The Constriction level of fruits also contributes to differentiate I. articulata, I. coerulea var. occidentalis, I. oblongifolia, I. sessiliflora, I. spiniflora and I. volkensii species from the other investigated taxa which are characterized by constricted fruits while the other taxa exhibit even fruits. It also points to the close relatioship between the I. Arabica, I. articulata, I. coerulea var. occidentalis, I. Linifolia, I. sessiliflora, I. spicata and I. spiniflora species which exhibit very close seeds being similar in hilum position. The fruits and seeds colour is more or less uniform in most investigated species. The seeds are circular, rectangular to irregular in shape.

In conclusion, the present study supports the use of seed morphological characters as a parameter for species identification. The results suggest both a close relationship between different species of Indigofera L. because there are different types of seed surfaces, seed shapes and epidermal cells similar each other from traditional species. 


\section{REFERENCES}

[1] B. D. Schrire, "Evolution of the Tribe Indigofereae (Leguminosae-Papilionoideae)," In: M. D Crisp and J. J. Doyle, Eds., Advances in Legume Systematics, Vol. 7, 1995, Royal Botanic Gardens, Kew, pp. 161-244.

[2] H. K. Airy Shaw, "A Dictionary of the Flowering Plants \& Ferns," 8th Edition, Cambridge University Press, Cambridge, 1985.

[3] D. J. Mabberley, “The Plant Book," 2nd Edition, Cambridge University Press, Cambridge, 1997.

[4] S. Collenette, "Wild Flowers of Saudi Arabia," National Commission for Wildlife Conservation and Development (NCWCD), Riyadh, Kingdom of Saudi Arabia, 1999.

[5] S. A. Chaudhary, "Flora of the Kingdom of Saudi Arabia (Vascular Plants), Vol. 1," National Agriculture and Water Research Center, National Herbarium, Ministry of Agriculture and Water, Riyadh, Saudi Arabia, 2001.

[6] I. De Kort and G. Thijsse, "A Revision of the Genus Indigofera (Leguminosae-Papilionoideae) in Southeast Asia,” Blumea, Vol. 30, No. 1, 1984, pp. 89-151.

[7] P. G. Wilson and R. Rowe, "The Indigofera trita Complex (Fabaceae: Indigofereae) in Australia,” Telopea, Vol. 5, No. 4, 1994, pp. 637-645.

[8] J. D. Brisson and R. L. Peterson, "A Critical Review of the Use of Scanning Electron Microscopy in the Study of Seed Coat," Scanning Electron Microscopy, Vol. 2, 1976, pp. 477-495.
[9] V. H. Heywood, "The Characteristics of the Scanning Electron Microscope and Their Importance in Biological Studies,” In: Scanning Electron Microscopy: Systematic and Evolutionary Applications, The Systematics Association Special Volume, Vol. 4, 1971, pp. 1-16.

[10] W. Barthlott, "Microstructural Features of Seed Surfaces," In: V. H. Heywood and D. M. Moore, Eds., Current Concepts in Plant Taxonomy, Academic Press, Cambridge, 1984.

[11] N. R. Lersten, "Testa Topography in Leguminosae Subfamily Papilionoidae," Proceedings of the Iowa Academy of Science, Vol. 88, No. 4, 1981, pp. 180-191.

[12] J. V. Suba Rao and S. R. Shannmukha Rao, "LM and SEM Studies in Seed Morphology in Some Tephrosia PERS. (Leguminosae)," Feddes Repertorium, Vol. 103, No. 5-6, 1992, pp. 339-343.

[13] S. A. Chaudhary and A. A. Al-Jawaid, "Vegetation of the Kingdom of Saudi Arabia,” Ministry of Agriculture and Water, Kingdom of Saudi Arabia, 1999.

[14] A. M. Migahid, "Flora of Saudi Arabia," 2nd Edition, Vol. 2, King Saud University Libraries Publication, 1989.

[15] L. Boulos, "Flora of Egypt Checklist," Revised Annotated Edition, Al-Hadara Publishing, Cairo, 2009.

[16] W. Barthlott and B. Ziegler, "Mikromorphologie der Samenschalen als systematischem Markmal bei Orchideen," Berichte der Deutschen Botanischen Gesellschaft, Vol. 24, 1981, pp. 267-273. 


\section{Key to the Studied Taxa Based on Seed Characters}

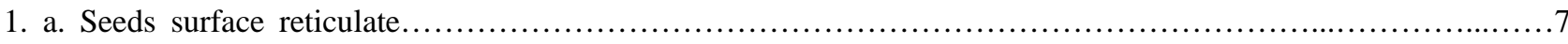

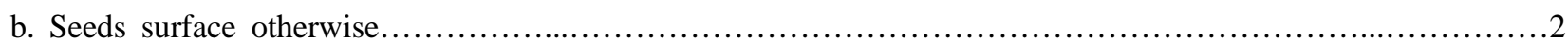

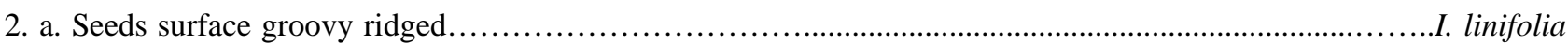

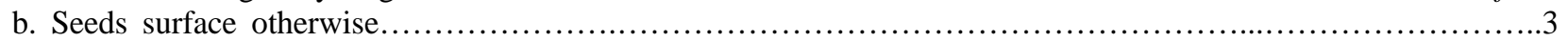

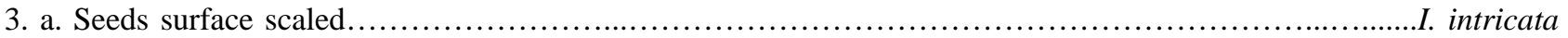

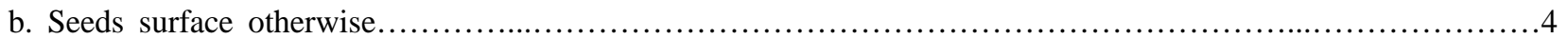

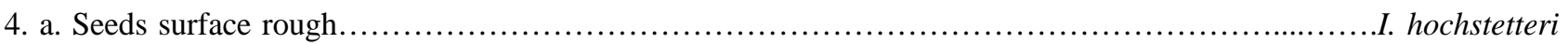

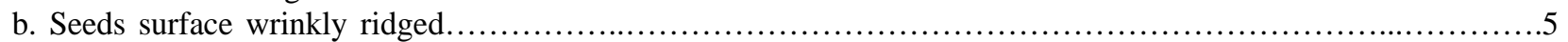

5. a. Hilum has ovate-shaped...................................................................................... trita var. subulata

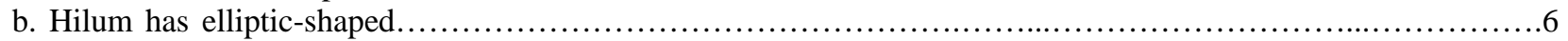

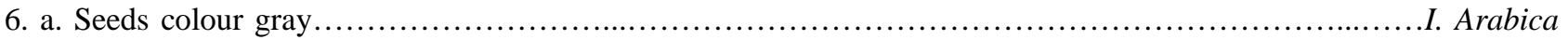

b. Seeds colour brown..................................................................................... volkensii

7. a. Seeds surface opened reticulate............................................................ sessiliflora

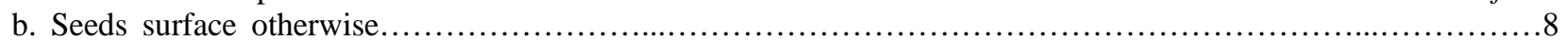

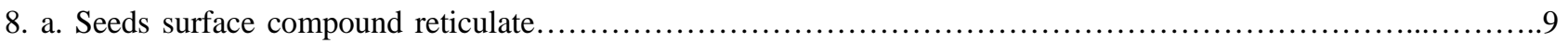

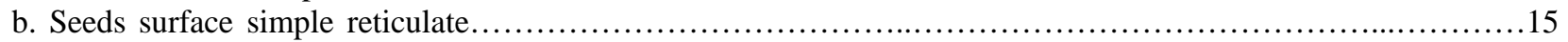

9. a. The outer and the inner reticulum are similar in thickness............................................. tinctoria

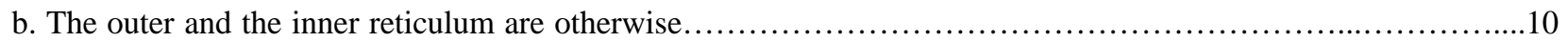

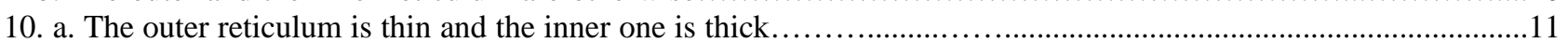

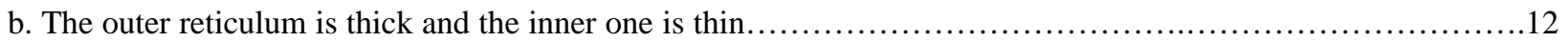

11. a. Seeds shape is rectangular without ornamentation...................................................... argentea

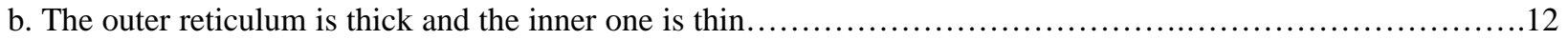

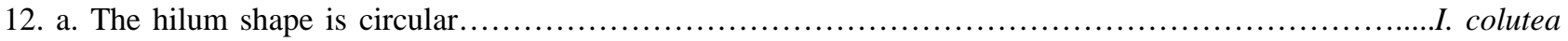

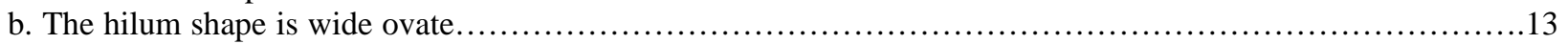

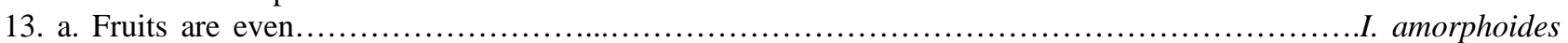

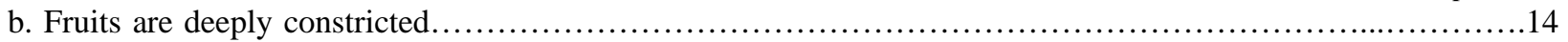

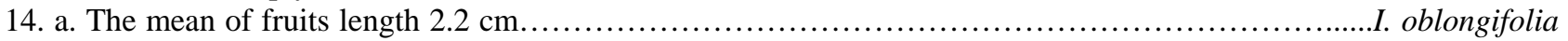

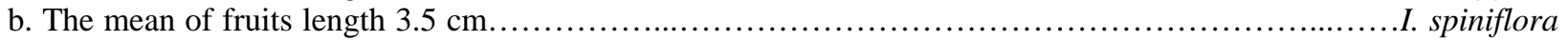

15. a. Seeds surface has simple regular reticulation............................................................ spinosa

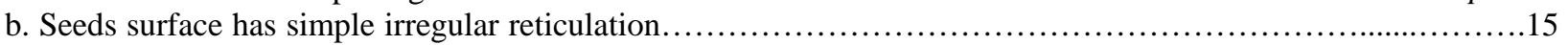

16. a. The hilum shape is ovate............................................................... coerulea var. occidentalis

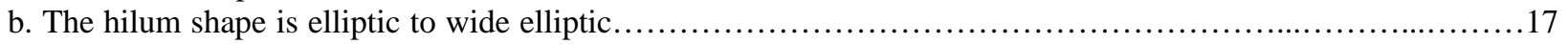

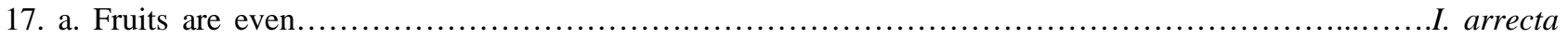

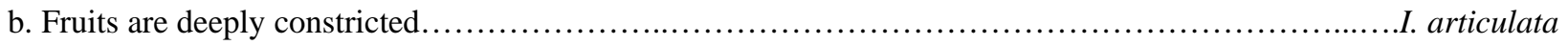

